\title{
MICROCYSTINS IN RAW WATER, DRINKING WATER, AND SOME ISOLATES OF CYANOPROKARYOTES
}

\author{
Mohammad I. Abdel-Hamid", Emad H. Abdel-Halim, Yehia A. Azab \\ Botany Department, Faculty of science, University of Mansoura 35516, \\ Mansoura, Egypt
}

\begin{abstract}
Raw water samples of two drinking water treatment plants (named New Mansoura and Bilqas stations) were collected for a full annual cycle. Analyses of total soluble inorganic N, dissolved reactive phosphorus (DRP) and Total dissolved phosphorus (TDP) were carried out. Qualitative and quantitative analysis of Cyanoprokaryotes and photosynthetic pigments of phytoplankton were investigated. Total microcystins of raw water supply and potable water were seasonally analyzed using ELISA. Seven Cyanobprokaryotes species were isolated, cultured under lab conditions and biomass contents of microcystin-LR and -YR were analyzed using HPLC. Physico-chemical characteristics and photosynthetic pigments displayed pronounced periodic variations. Species composition and abundance of Cyanoprokaryotes exhibited marked seasonal variation during the period of study. Cyanoprokaryotes biovolume peaked in summer at New Mansoura $\left(214.3 \mathrm{~mm}^{3} \mathrm{~m}^{-3}\right)$ and Bilqas $\left(161.3 \mathrm{~mm}^{3} \mathrm{~m}^{-3}\right)$ water treatment stations. The minimum mean biovolume of 25.2 and $30.8 \mathrm{~mm}^{3} \mathrm{~m}^{-3}$ were recorded in winter at New Mansoura and in autumn at Bilqas station, respectively. Total microcystins in raw water maintained seasonal variations. Microcystins values were 2.2 and $2.0 \mu \mathrm{g} \mathrm{l}^{-1}$ during summer at Bilqas and New Mansoura respectively. Theses values of $1 \mu \mathrm{g} \mathrm{l}^{-1}$ exceeding the WHO guidelines. Total microcystins of potable water were below the WHO guideline except in summer at New Mansoura $\left(1.2 \mu \mathrm{g}^{-1}\right)$. Microcystins in biomass of different species of Cyanoprokaryotes varied between $3.0 \mathrm{mg} \mathrm{g}^{-1}$ (8\% LR and 92\% YR) and $0.3 \mathrm{mg}$ $\mathrm{g}^{-1}(100 \% \mathrm{LR})$ recorded for Anabaena oryzae and Anabaena khannae, respectively.
\end{abstract}

Keywords: Cyanoprokaryotes, Cyanotoxins, Drinking water, Microcystins.

\section{Introduction}

Dense human settlements, intensive agricultural activities and heavy industrialization along with deficient water management have led to the enhancement of eutrophication of surface freshwater bodies exerting negative consequence on quality of drinking water resources. Eutrophication embraces any activities that contribute to an increase of plant nutrients, mainly phosphorus and nitrogen in water body (Skulberg, 1980). The enrichment of water bodies by nutrients is often followed by a heavy growth or even blooming of the resident algal communities, and therefore, eutrophication has become a problem receiving 
a great environmental concern. It has been reported elsewhere that, eutrophication stimulate profuse growth of blue green algae (Cyanoprokaryotes), mostly Microcystis, Anabaena, Oscillatoria (Skulberg et al., 1984). Certain species belonging to these genera are producers of a wide variety of toxins extremely hazardous to the environment and man (Skulberg, et al., 1984; Skulberg 1989).

Blooms of toxic Cyanobprokaryotes have been reported worldwide and several incident of wild domestic animal poisoning as well as human injury and death have been reported (Carmichael, 2001; Cook et al., 2004; Falconer, 2005). Hepatotoxic cyclic peptide toxins (microcystins and nodularins) are the most widespread cyanotoxins that are present in diverse environments. Microcystins are cyclic heptapeptides that are produced by different Cyanoprkaryotes genera such as Microcystis, Anabaena, Oscillatoria (Plankothrix) and Nostoc (Spoof, 2004). The heptotoxic microcystin contain three $\mathrm{D}$-amino acids, two variable $\mathrm{L}-$ amino acids, and two unusual amino acids $\mathrm{N}-$ phenyldeca -4, 6-dienoic acid (Carmichael, 1988).

The toxicity of microcystins is associated with irreversible binding and inhibition of protein phosphotases 1 and 2A in the liver (Mackintosh et al., 1990; Matsushima et al., 1990). Except the study carried out by Mohammed and Carmichael (2000) who analyzed total microcystins in drinking water resources in Sohag City in Egypt, investigation of microcystins in surface raw and potable water in Egypt received no or a very little attention. The River Nile is the major source of freshwater in Egypt, contributing by $96 \%$ of the total annual freshwater budget (MWRI, 2005). Since the eutrophic water of the Nile River favor the growth and biomass development of Cyanoprokaryotes, it seems a must to carry out regular analysis of microcystins in raw and potable water. This view is greatly supported by the fact that the WHO (1998) has already set microcystin guideline $\left(\leq 1.0 \mu \mathrm{g}^{-1}\right)$ for drinking water. The present study aims primarily to record the weekly variation in species composition and abundance of planktonic Cyanoprokaryotes of surface raw water supply to two major drinking water treatment plants with special emphasis on seasonal variation of total microcystins in raw, potable water and biomass of seven different Cyanoprokaryotes species isolated from the raw water supply. The present study pertain special significance for drinking water quality management in Egypt as it provides base information about Cyanoprokaryotes toxins in surface and drinking waters. The information may be necessary for setting up national guidelines for microcystins of health safe drinking water.

\section{Material and Methods}

\section{Study area}

Two major drinking water treatment plants (New Mansoura and Bilqas plants) in Dakahlia Governorate were selected for regular sampling during the study. The geographical location of the treatment plants is illustrated in Fig. 1.

Egyptian J. of Phycol. Vol. 13, $2012 \quad$ - 2 - 


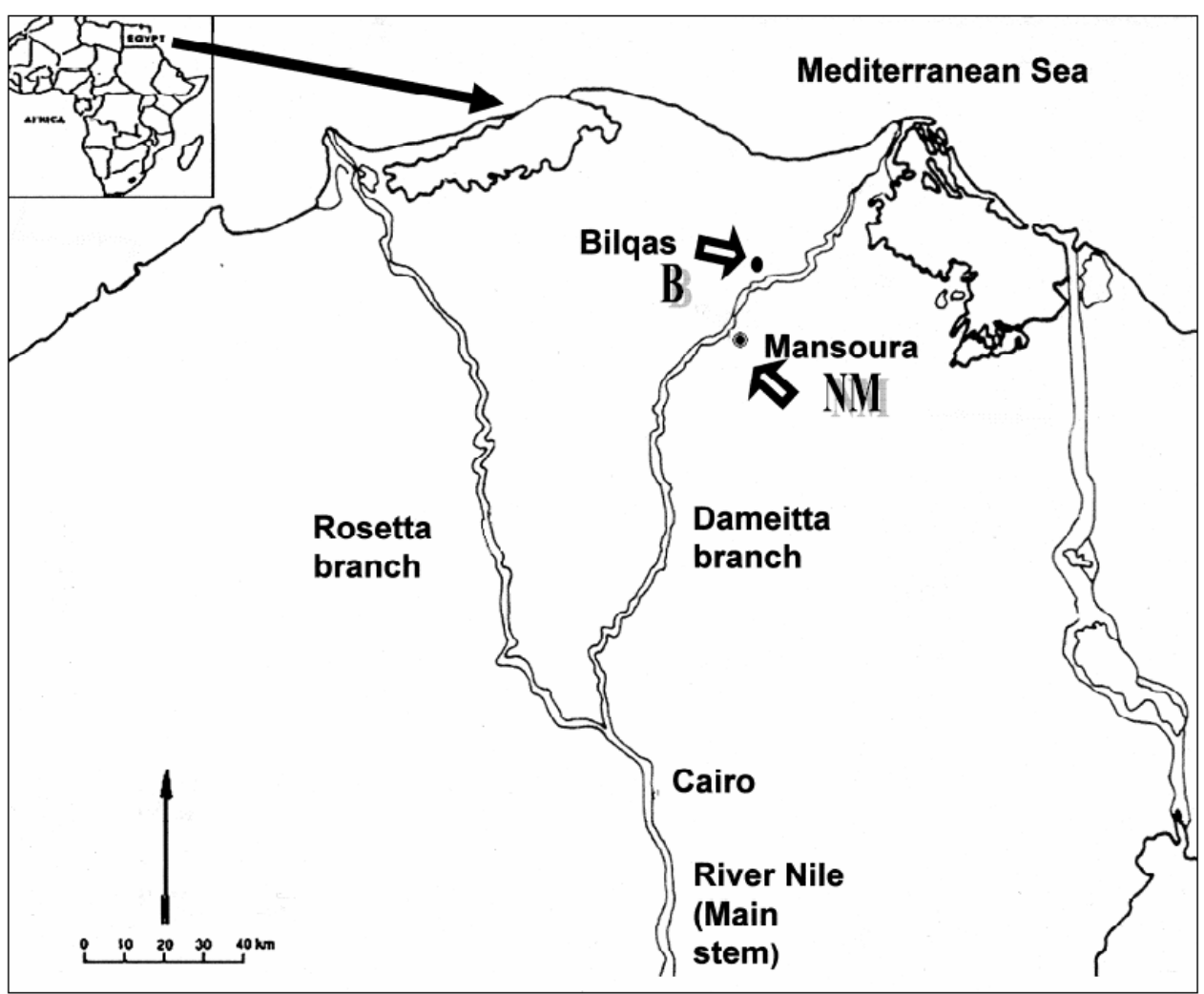

Figure (1): A map showing the geographical location of the study stations. Short arrows point to the sampling sites.

\section{Sampling}

Raw surface freshwater samples were weekly collected during a full annual cycle (summer 2009 - spring 2010) using clean dry polyethylene bottles. A total of 52 raw water samples were collected from each sampling station with each season represented by 13 water samples. Raw and potable water samples were seasonally collected for the analysis of total microcystins. Sample collection, handling and processing followed APHA (2005).

\section{Sample preparation}

One liter of raw water samples were preserved (Prescott, 1978) with $1 \%$ Lugol's solution for qualitative and quantitative analysis of phytoplankton communities including Cyanoprokaryotes. Four liters of raw water samples were filtered through GF/C Whatman glass fiber filters. The first one liter filtrate was discarded, and three liters were immediately stored at $4{ }^{\circ} \mathrm{C}$ in dark to be used for different chemical analysis. 


\section{Physico-chemical analysis}

Water temperature and $\mathrm{pH}$ were directly measured at field using a Jenway dual temperature and $\mathrm{pH}$ meter model 370, total dissolved salts (TDS) was measured using Martini MI 170 bench meter. Nitrite-N, nitrate-N, ammonium-N, dissolved reactive phosphorus (DRP) and Total dissolved phosphorus (TDP) were spectrophotometrically analyzed according to the standard methods described in APHA (2005).

\section{Analysis of photosynthetic pigments}

A known volume of raw water samples was filtered through GF/C filters, ground using PTFE/glass tissue grinder in presence of $10 \mathrm{ml}$ of cool $90 \%$ aqueous acetone, transferred to centrifuge tubes and kept in dark for 12 hours at $4^{\circ} \mathrm{C}$ for extraction. Chlorophyll $a$ and $c$ were determined according to the formulas of Jeffrey and Humphery (1975), while carotenoids were determined according to (Metzner et al., 1965).

\section{Qualitative and quantitative analysis of Cyanoprokaryotes}

Fixed planktonic Cyanoprokaryotes were identified according to Desikachary (1959), Anagnostids and Komárek (1985, 1988, 1990), Komárek and Anagnostids $(1986,1989)$ and Prescott $(1982)$. The quantitative analysis of planktonic Cyanoprokaryotes followed Utermöhl, (1958). Dimensions of at least, 20 cells of each taxon were measured to calculate the mean cell volume (MCV) using appropriate geometric formula (Rott, 1981). The total cell number per each taxon was multiplied by the corresponding MCV to calculate the biovolume of the taxon. The biovolumes of different taxa were summed to calculate the total biovolume of planktonic Cyanoprokaryotes communities.

\section{Isolation and culturing of Cyanoprokaryotes}

Raw water samples were collected, centrifuged and the greenish pellet was streaked on agar plate containing BG-11 medium (Stanier et al., 1971). The plates were incubated at $25 \pm 2^{\circ} \mathrm{C}$ and irradiance of $24 \mu$ mole $\mathrm{m}^{-2} \mathrm{~s}^{-1}$. After one week, the separate Cyanoprokaryotes filaments were aseptically picked up with sterilized needle, streaked again on the agar plates containing BG-11 medium and left to grown under the same conditions. This procedure resulted in obtaining seven different Cyanoprokaryotes species namely, Anabaena khannae Skuja, Anabaena oryzae Fritsch, Nostoc linckia (Roth) Bornetex Born. et Flash , Planktolyngbya borgerti Lemm, Planktolyngbya limnetica (Lemmermann) J. Komárková-Legnerová and G. Cronberg, Pseudanabaena limnetca (Lemm.) Kom. and Westiellopsis prolifica Janet, The isolated species were separately grow in two liters culture flask, each containing $500 \mathrm{ml}$ of BG-11 medium, incubated under same growth condition for 7 days to obtain biomass for microcystin analysis. 


\section{Microcystins analysis in water samples}

Raw and potable water samples were treated twice by freeze thawing and filtration using GF/C then total microcystins concentration was determined by enzyme linked immunosorbent assay (ELISA) using Abraxis microcystinsADDA ELISA kits microtiter plate (Abraxis LLC 54 Streamwhistle Drive, Warminster, PA 18974, USA). This kit was verified and approved by The Environmental Technology Verification (ETV) Program of the U.S EPA (2010). Eight plastic strips contain 8 wells of $200 \mu$ capacity and a hard plastic frame that firmly holds the strips was provided with the Kits. Although a leaflet of standard assay procedure along with a video instruction movie was provided, it may be desirable to point out the whole procedure in a concise and precise manner as follows. To obtain a standard curve for microcystin analysis 50 $\mu \mathrm{l}$ of different standard microcystin solution $\left(0,150,400,750,1000,2000\right.$ and $\left.5000 \mathrm{ng} \mathrm{l}^{-1}\right)$ was added to different wells followed by the addition of $50 \mu 1$ of antibody solution.

The strips containing wells was covered with parafilm, firmly fixed in the strip holder and shaken in a rapid circular motion for $30 \mathrm{sec}$, and incubated at room temperature for $90 \mathrm{~min}$. After incubation, the parafilm was removed, the content of wells was shaken vigorously into the sink and the wells were washed using $1 \mathrm{x}$ buffer solution. A volume of $100 \mu \mathrm{l}$ of enzyme conjugate was then added to the individual wells, the strips were covered with parafilm, shaken in a rapid circular motion for $30 \mathrm{sec}$ and incubated at room temperature for $30 \mathrm{~min}$, contents were shaken vigorously into the sink and wells were washed with $1 \mathrm{x}$ buffer solution. A volume of $100 \mu 1$ of color solution was then added to individual wells, and then the strips containing wells were left to stand for $30 \mathrm{~min}$ at room temperature avoiding any direct sunlight. Finally $50 \mu 1$ of stop solution was added to each well and the absorbance of the developed color was read at $450 \mathrm{~nm}$ was read using DIAREADER ELX800G microplate reader.

The prism 5.0 software program was used to plot a standard curve for the $\log$ concentration of microcystins against the corresponding relative absorbance of $\left(\% \mathrm{~B} / \mathrm{B}_{0}\right)$ where $\mathrm{B}$ was the absorbance of standard solution and $\mathrm{B}_{0}$ was the absorbance of blank solution(Zero standard).

The above procedure was identically carried out for the analysis of total microcystins in raw and potable water samples. Different samples absorbance was matched against the standard curve to obtain total microcystins concentration. Each test was carried out in triplicate. The detection limit of this test is $100 \mathrm{ng} \mathrm{l}^{-1}$. Figure (2) represent an example of the standard curve. 


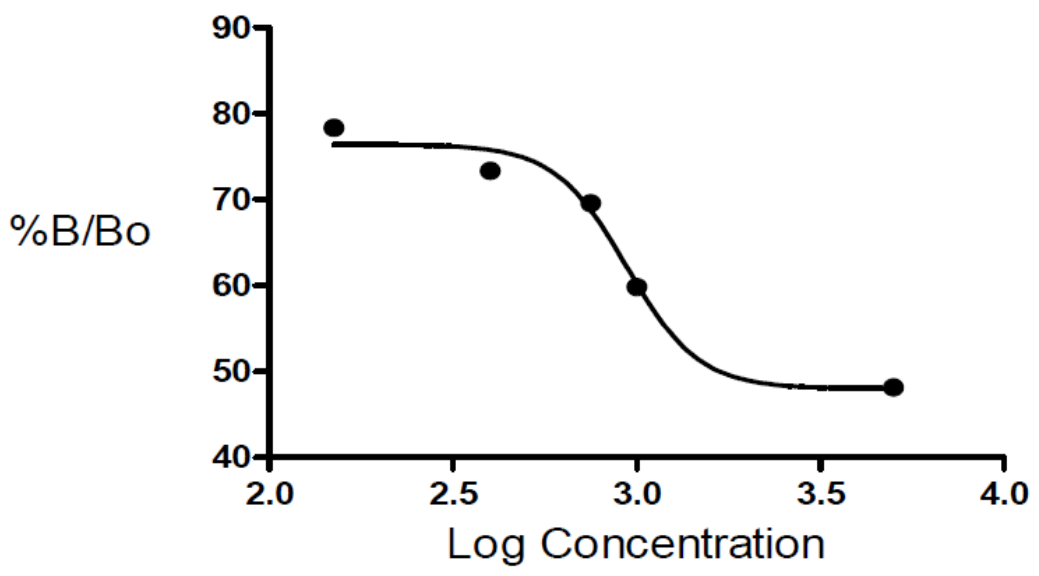

Figure (2): An example of standard curve used for calculation of total microcystins

\section{Microcystins analysis in cyanoprokaryotes isolates}

Microcystins in biomass of different of isolated species of Cyanoptokaryotes were extracted by homogenizing of $1.0 \mathrm{~g}$ of freeze-dried biomass in $20 \mathrm{ml}$ cold methanol 95\%. Extracted for one hour with stirring at room temperature, then the methanol was collected into a clean glass tube. The extraction process was repeated thee times using fresh cold 95\% methanol. The extract was centrifuged at 10,000 rpm for 10 minutes and the supernatants of each extract were combined together, poured into dry clean $150 \mathrm{ml}$ flask, and the organic solvent was blown with sterilized air. The remaining concentrated extract (about $5.0 \mathrm{ml}$ ) was filtered through $\mathrm{GF} / \mathrm{C}$ filter paper. The filtered fraction was applied directly to preconditioned C18 cartridges for solid phase extraction (SPE) according to Carmichael and An (1999). The toxins were eluted with methanol $80 \%$, evaporated to dryness, reconstituted in $1.0 \mathrm{ml}$ methanol and applied to Agilent 1100 high performance liquid chromatography (HPLC) provided with UV dioarray detector set at $238 \mathrm{~nm}$ and Zorbax C18 column $(250 \mathrm{~mm} \times 4.6 \mathrm{~mm})$. The mobile phase comprises methanol and $2 \%$ ammonium acetate at volumetric ratio of (30:20) (v/v), applied at room temperature with flow rate of $1 \mathrm{ml} \mathrm{min}{ }^{-1}$. Standard microcystin- LR and YR (Abraxis LLC) was used to calibrate the HPLC.

\section{Statistical analysis}

Summary statistics and correlation analyses were carried out using STATICA for windows release 4.5 (Stat soft, Inc.1993) software program. 


\section{Results}

\section{Physico-chemical characteristics of raw water samples}

Site to site variations in mean values of physical and chemical parameters were marginal and negligible, however pronounced seasonal variation were evident for some parameters, including, for instance, water temperature as the highest value of $31.5^{\circ} \mathrm{C}$ was recorded in summer and the lowest of $14.0^{\circ} \mathrm{C}$ recorded in winter (Table 1).

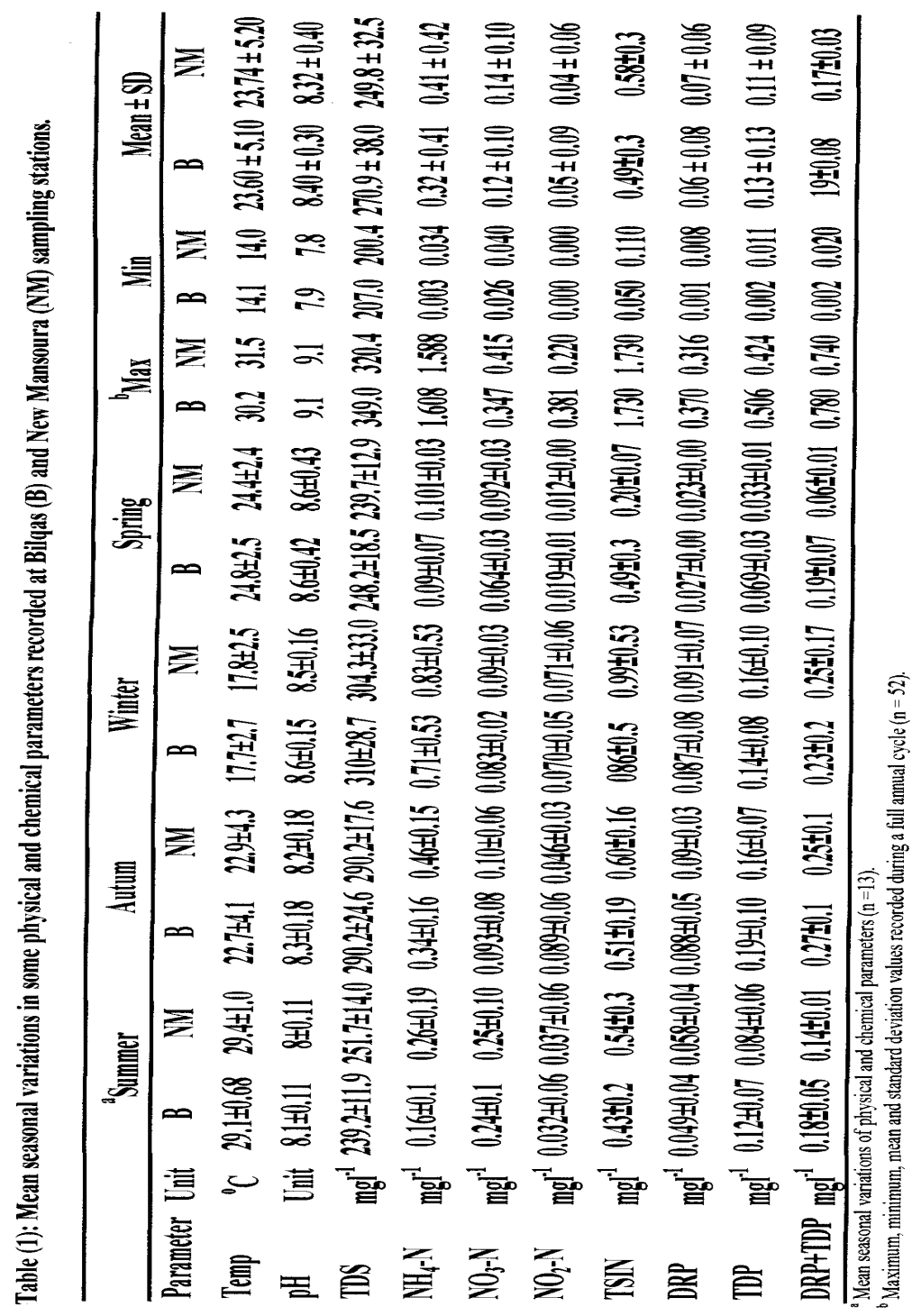


The mean values of total soluble inorganic nitrogen $($ TSIN $=$ sum concentrations of $\mathrm{NO}_{2}-\mathrm{N}, \mathrm{NO}_{3}-\mathrm{N}$, and $\mathrm{NH}_{4}-\mathrm{N}$ ) displayed obvious seasonal variations with the highest annual value of $1.73 \mathrm{mg} \mathrm{l}^{-1}$ recorded at New Mansoura and $1.73 \mathrm{mgl}^{-1}$ at Bilqas and the lowest ones was $0.11 \mathrm{mg} \mathrm{l}^{-1}$ at New Mansoura and $0.05 \mathrm{mg} \mathrm{l}^{-1}$ at Bilqas recorded in winter and spring seasons respectively (Table 1). It has been noticed that TSIN largely composed of NH4-N through the whole period of study. The dissolved reactive phosphorus (DRP) + Total dissolved phosphorus (TDP) ranged between 0.002 to $0.74 \mathrm{mg} \mathrm{l}^{-1}$ (Table 1). Mean seasonal variations in concentrations of TSIN and (DRP+TDP) are shown in Figures $3 \mathrm{a}$ and $3 \mathrm{~b}$ respectively.
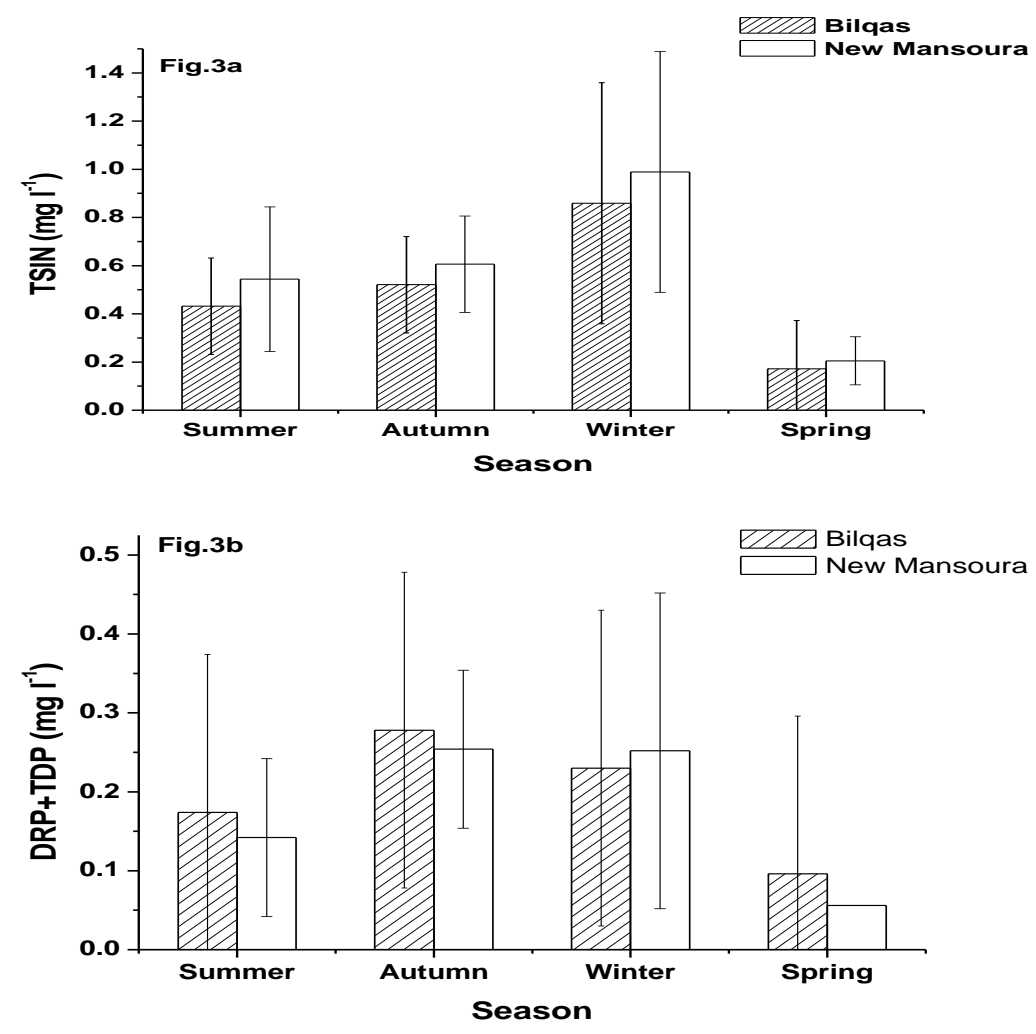

Figure (3): Mean seasonal variations in total soluble inorganic nitrogen (TSIN) (Fig. 3a) and (DRP+TDP) (Fig. 3b) at New Mansoura and Bilqas sampling stations Photosynthetic pigments

On an annual basis, the concentration of chlorophyll $a$ varied widely between 1.91 and $19.46 \mathrm{mg} \mathrm{m}^{-3}$ at New Mansoura and between 1.75 and $27.5 \mathrm{mg}$ $\mathrm{m}^{-3}$ at Bilqas (Table 2). Mean seasonal variations (mean values of 13 different 
analyses per season) in concentration of the photosynthetic pigments analyzed at New Mansoura and Bilqas are shown in Figs. $4 \mathrm{a}$ and b. As seen from the figures, substantial site to site difference in concentration of chlorophyll $a$ was evident, for instance, in summer the main chlorophyll $a$ concentration was $19.7 \pm 3.22$ and $10.7 \pm 2.20 \mathrm{mg} \mathrm{m}^{-3}$ at Bilqas and New Mansoura respectively. Based on the seasonal trends, the concentration of photosynthetic pigments (mainly chlorophyll $a$ and carotenoids) were almost significantly $(\mathrm{P} \leq 0.05)$ higher at Bilqas compared to New Mansoura station.

Table (2): Maximum, minimum and mean values $(n=52)$ of planktonic photosynthetic pigments recorded at Bilqas (B) and New Mansoura (NM).

\begin{tabular}{|l|c|c|c|c|c|c|c|}
\hline \multicolumn{2}{|c|}{} & \multicolumn{2}{c|}{ Max } & \multicolumn{2}{c|}{ Min } & \multicolumn{2}{c|}{ Mean \pm SD } \\
\hline Parameter & Unit & B & NM & B & NM & B & NM \\
\hline Chlorophyll $a$ & mgm $^{-3}$ & 27.50 & 19.46 & 1.75 & 1.91 & $12.94 \pm 7.09$ & $\mathbf{8 . 8 6} \pm 4.23$ \\
\hline Chlorophyll $c$ & mgm $^{-3}$ & 12.98 & 5.70 & 0.14 & 0.15 & $2.59 \pm 2.06$ & $2.15 \pm 1.41$ \\
\hline Carotenoids & mgm $^{-3}$ & 12.05 & 10.71 & 1.31 & $\mathbf{0 . 6 0}$ & $5.32 \pm 2.87$ & $4.01 \pm 2.13$ \\
\hline
\end{tabular}
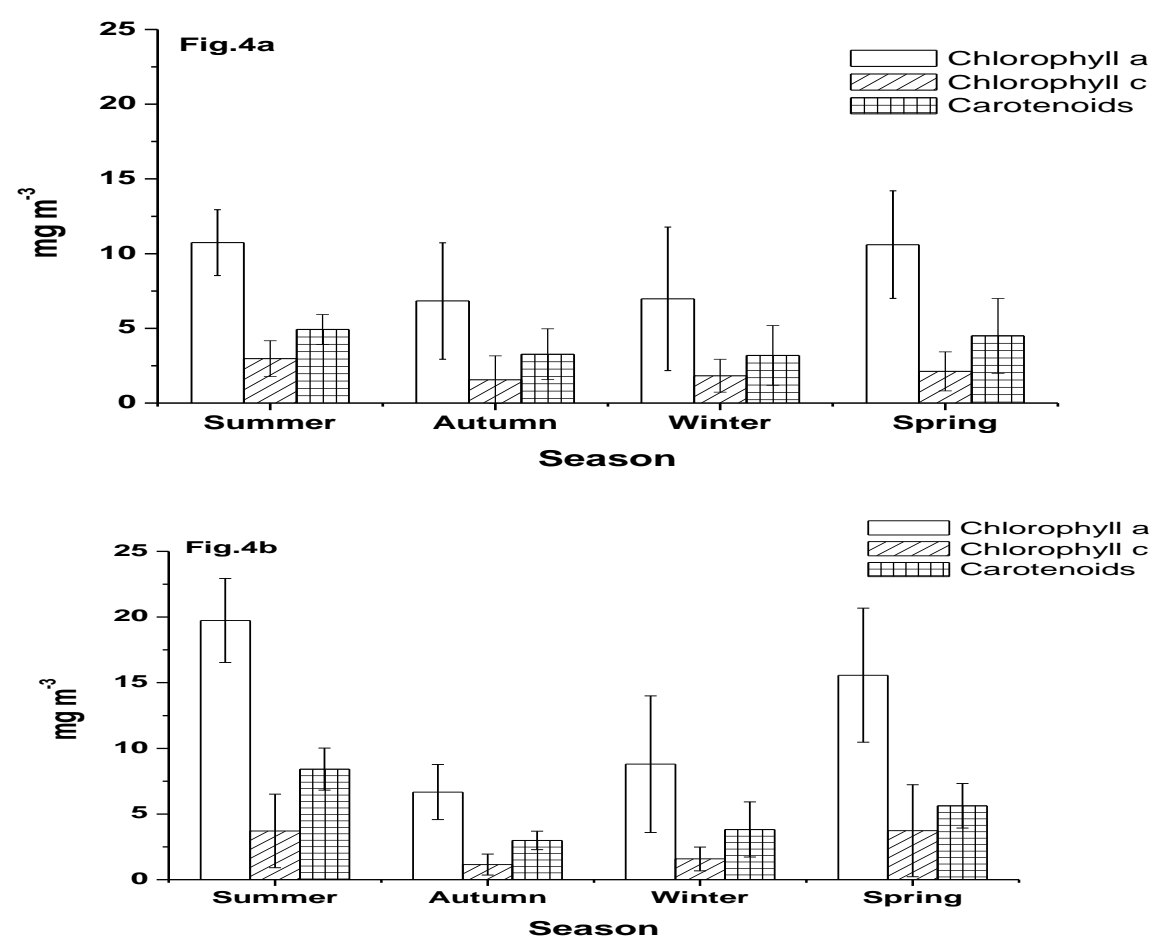

Figure (4): Mean seasonal variations of photosynthetic pigments chl $a, \operatorname{chl} c$ and carotenoids of raw water collected from New Mansoura (Fig. 4a) and Bilqas (Fig. 4b) sampling stations. 


\section{Species composition and abundance of Cyanoprokaryotes}

A total of 40 different species of Cyanoprokaryotes were identified during this study. In terms of species number, Cyanoprokaryotes was mainly composed of members of Chroococcales (25), followed by Oscillatoriales (11), and, a little extent, by members of Nostocales (4).

Great seasonal variations in species number were observed (Table 3) with the highest number of 35 species recorded in summer and the lowest of 21 species recorded in winter. During the four seasons, the Cyanoprokaryotes community was mainly represented by Chroococcales, followed by Oscillatoriales and Nostocales (Table 3). Figure 5 illustrates and compares the Cyanoprokaryotes species richness at both sampling stations; it is also evident that the highest and the lowest number of different species were recorded in summer and winter, respectively.

Table (3): Seasonal variations of cyanoprokaryotes belonging to different taxonomic orders.

\begin{tabular}{|l|c|c|c|c|}
\hline Cyanoprokayote class & Summer & Autumn & Winter & Spring \\
\hline Chroococcales & $\mathbf{2 4}$ & $\mathbf{1 4}$ & $\mathbf{1 4}$ & $\mathbf{1 5}$ \\
\hline Oscillatoriales & $\mathbf{9}$ & $\mathbf{6}$ & $\mathbf{5}$ & $\mathbf{5}$ \\
\hline Nostocales & 2 & $\mathbf{2}$ & $\mathbf{2}$ & 3 \\
\hline Total species number & $\mathbf{3 5}$ & $\mathbf{2 2}$ & $\mathbf{2 1}$ & $\mathbf{2 3}$ \\
\hline
\end{tabular}

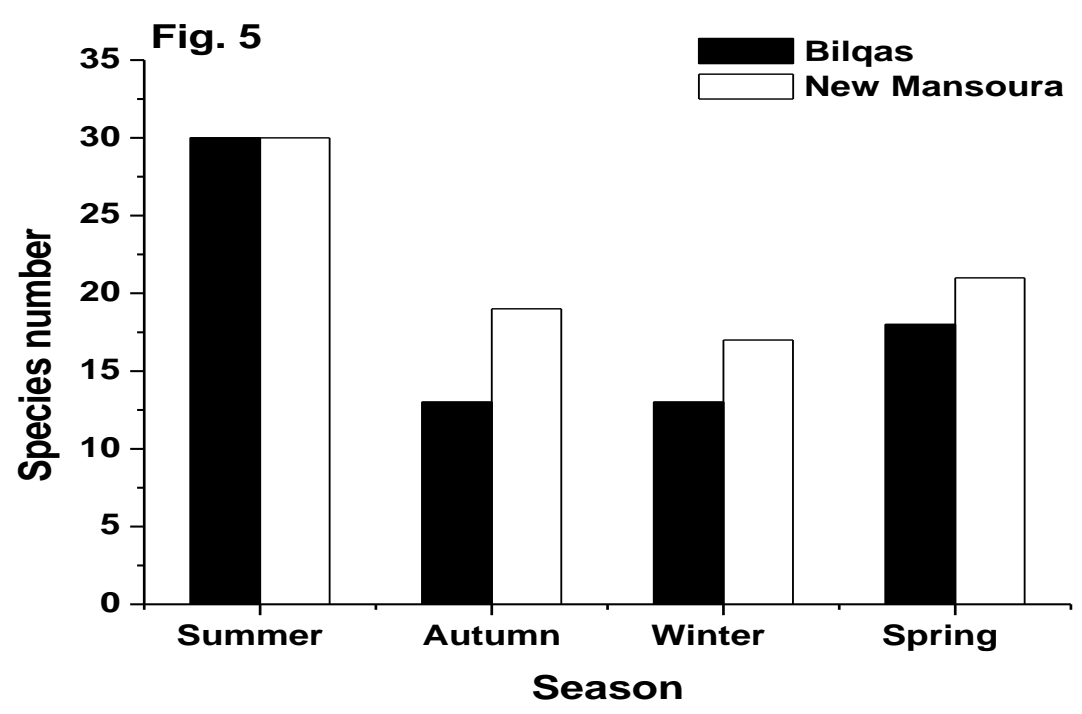

Figure (5): Seasonal variation in total species number of Cyanoprokaryotes recorded at New Mansoura and Bilqas sampling stations. 
The terms biomass, biovolume and standing crop will be repeatedly mentioned, and all describe the phytoplankton abundance and expressed as $\mathrm{mm}^{3} \mathrm{~m}^{-3}$. As seen from Table 4, the fresh weight biomass exhibited substantial site to site and seasonal variations. Only 9 different species namely, Aphanocapsa delicatissimia, Chroococcus dispersus var. minor, C. minor, Coelosphaerium dubium, Merismopedia punctata, Microcystis aeruginosa, Oscillatoria formosa, O. limnetica, O. minima persistent during the whole period of study, exhibiting marked seasonal and local variations (Table 4).

Table (4): Mean seasonal variations in biovolume of different planktonic cyanoprokaryotes species identified during the study period at Bilqas (B) sampling

\begin{tabular}{|c|c|c|c|c|c|c|c|c|}
\hline \multirow{3}{*}{$\begin{array}{l}\text { Cyanobacterial species } \\
\text { Order : Chroococcales }\end{array}$} & \multicolumn{8}{|c|}{ Menn biovolume $\mathrm{mm}^{3} \mathrm{~m}^{-3}$} \\
\hline & \multicolumn{2}{|c|}{ Summer } & \multicolumn{2}{|c|}{ Autumn } & \multicolumn{2}{|c|}{ Winter } & \multicolumn{2}{|c|}{ Spring } \\
\hline & NM & B & NM & B & NM & B & NM & B \\
\hline Aphonocapsa delicatissimia West\&West. & 0.05 & 0.13 & 0.02 & 0.03 & 0.05 & 0.04 & 0.06 & 0.04 \\
\hline A. elashista var .conjerta West\&West. & 0.73 & 0.51 & 0.29 & - & - & - & 0.09 & 0.18 \\
\hline A. pulchra (Kuetz.) Rab enhor st. & 1.26 & - & - & - & - & - & - & - \\
\hline Aphonocapsa sp. & 0.32 & 0.33 & 0.01 & - & 0.03 & - & 0.12 & 0.46 \\
\hline Aphanothece microspora (Menegh.) Rab enh or st. & - & 0.03 & - & - & - & - & - & 1.15 \\
\hline Chroococcus dispersus (Keissl.) Lemm. & 1.79 & 1.11 & 0.43 & - & 0.23 & 0.25 & - & - \\
\hline C. dispersus var. minor G.M. Smith. & 0.81 & 0.89 & 0.10 & 0.05 & - & 0.05 & 0.13 & 0.12 \\
\hline C. minor (Kuetz.) Na egeli. & 3.12 & 3.31 & 2.20 & 3.57 & 1.11 & 1.29 & 1.17 & 1.00 \\
\hline C. minutus (Kuetz.) Naegeli. & 5.98 & 7.67 & 1.26 & - & - & - & - & - \\
\hline C. pallidus Naegeli. & - & 0.38 & 0.65 & - & - & 1.22 & - & - \\
\hline Chroococcus sp. & 0.04 & 0.11 & - & - & 0.01 & - & - & - \\
\hline Coelosphaerium dubium Grunow. & 55.13 & 43.04 & - & 1.34 & 2.42 & 2990 & 6.32 & 20.76 \\
\hline C. kuetzingiconum Na egeli. & 5.58 & 2.38 & - & 0.00 & 0.57 & - & 3.20 & 2.43 \\
\hline C. ncegelianum Unger. & 3.45 & 4.45 & - & - & - & - & 0.64 & 6.01 \\
\hline C. pallichum Lemm. & 0.83 & 1.18 & 0.08 & 0.10 & - & - & - & - \\
\hline Coelospherim. Sp. & 0.15 & 1.82 & - & - & - & - & - & - \\
\hline Gleocapsa sp. & 0.39 & 1.83 & 1.45 & - & 0.20 & - & - & - \\
\hline Merismopedia convoluta de $\mathrm{Br} \mathrm{eb}$. & 10.08 & 3.28 & - & - & - & - & 2.61 & 10.27 \\
\hline M. elegcons A.Braun. & 20.89 & 12.51 & - & - & - & - & 7.60 & 9.20 \\
\hline M. glauca (Ehr enb.) Naegeli & 7.76 & 12.63 & 5.95 & 1.74 & - & - & - & 2.13 \\
\hline M. punctata Mey en. & 2.44 & 598 & 0.56 & 0.30 & 0.25 & 0.48 & 0.29 & - \\
\hline Merismopedia sp. & 1.63 & 0.00 & - & - & - & - & - & - \\
\hline Microcystis aenuginosa Kuetz., Emend. & 53.61 & 40.40 & 7.91 & - & - & 10.00 & 7.34 & 17.60 \\
\hline M. inserta Kuetz. & - & - & - & - & 0.08 & 0.17 & - & - \\
\hline Synechococcus sp. & 0.22 & - & - & - & 3.60 & 2.05 & 1.96 & - \\
\hline Total biovolume of Chroococcales & 176.25 & 14396 & 20.91 & 7.13 & 8.54 & 45.44 & 3153 & 71.37 \\
\hline \multicolumn{9}{|l|}{ Order : Nostocales } \\
\hline Anabaena circinalis Rabenhorst. & - & - & - & - & - & - & 1.20 & 1.40 \\
\hline A. naviculoides Fritsch. & - & - & 15.25 & - & - & - & - & - \\
\hline Anabaena sp. & - & 0.34 & 0.80 & 2.39 & 0.50 & - & 0.43 & 4.20 \\
\hline Westielopsis prolifica Jan et. & 2.68 & - & - & - & 2.77 & 5.05 & 10.08 & 42.75 \\
\hline Total biovolume of Nostocales & 2.68 & 0.34 & 16.05 & 2.39 & 3.27 & 5.05 & 11.71 & 48.35 \\
\hline \multicolumn{9}{|l|}{ Order: Oscilltoriales } \\
\hline Oscillatoria angusta Koppe. & - & 0.34 & - & - & - & - & - & - \\
\hline O. articulata Gardner. & - & 1.30 & - & 5.13 & - & - & - & - \\
\hline O. chalyba Merten. & - & - & 13.10 & - & - & - & 4.13 & - \\
\hline O. formosa Bory. & 19.96 & 894 & 10.34 & 8.85 & 7.17 & 2.60 & 25.28 & 27.48 \\
\hline o. limnetica Lemm. & 0.23 & 1.11 & 1.90 & 2.54 & 1.98 & 1.43 & 1.73 & 8.30 \\
\hline O. minima Gick Ihorn. & 3.80 & 1.62 & 1.13 & 3.73 & 0.37 & - & 0.69 & - \\
\hline O.princeps Vaucher. & 2.78 & 0.76 & - & - & - & - & - & - \\
\hline O. tenuis C.A Agar dhi. & 7.79 & - & - & 1.08 & - & - & 1.26 & - \\
\hline Oscillatoria sp. & 0.11 & 0.37 & - & - & 0.13 & - & - & - \\
\hline Psendanabaena sp. & 0.74 & 2.60 & - & - & - & - & - & - \\
\hline Planktolyngbya sp. & - & - & - & - & 3.70 & 0.74 & - & - \\
\hline Total biovolume of Oscillatoriales & 35.40 & 17.02 & 26.47 & 21.33 & 13.35 & 4.77 & 33.09 & 35.78 \\
\hline Total biovolume & 214.33 & 161.33 & 63.43 & 30.84 & 25.16 & 55.26 & 76.33 & 155.50 \\
\hline
\end{tabular}


and New Mansoura (NM) stations.

An elegant observation was the summer predominance of the colonial species of Coelosphaerium dubium $\left(55.1 \mathrm{~mm}^{3} \mathrm{~m}^{-3}\right.$ at New Mansoura and 43.0 $\mathrm{mm}^{3} \mathrm{~m}^{-3}$ at Bilqas) and Microcystis aeruginosa $\left(53.6 \mathrm{~mm}^{3} \mathrm{~m}^{-3}\right.$ at New Mansoura and $40.4 \mathrm{~mm}^{3} \mathrm{~m}^{-3}$ at Bilqas) (Table 4).Westiellopsis prolifica maintained significantly growth during spring at Bilqas $\left(42.8 \mathrm{~mm}^{3} \mathrm{~m}^{-3}\right)$ and New Mansoura $\left(10.0 \mathrm{~mm}^{3} \mathrm{~m}^{-3}\right)$ stations.

Seasonal variations in mean standing crop of Cyanoprokaryotes at New Mansoura and Bilqas are clearly illustrated in Fig. 6a and 6b, respectively. Biovolume contributions of Chroococcales,
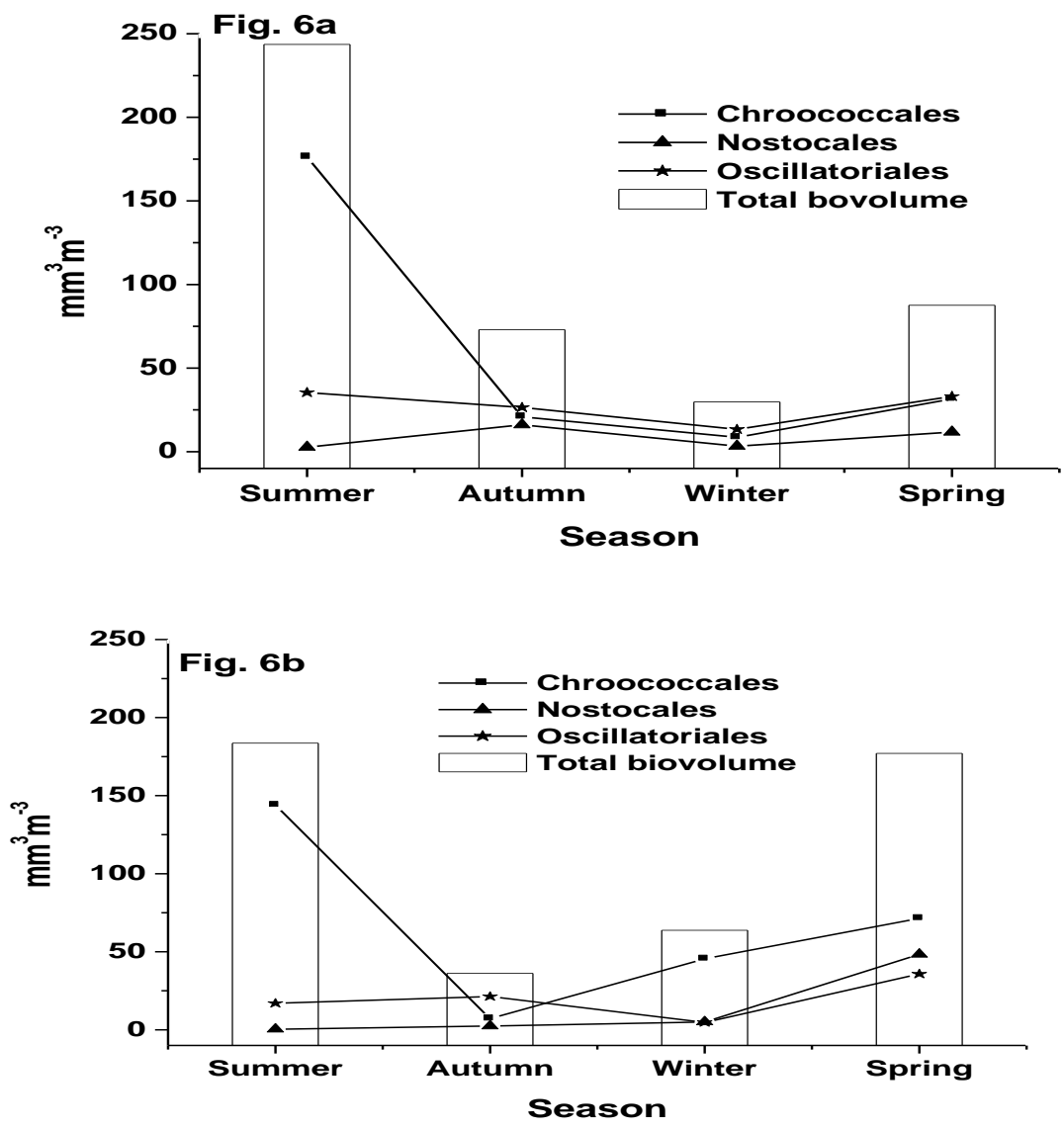

Figure (6): Mean seasonal variations in abundance of Cyanoprokaryotes community of the raw intake water of New Mansoura (Fig. 6a) and Bilqas (Fig. 6b) sampling stations. 
Oscillatoriales and Nostocales were also shown. It is evident that the mean total biovolume of Cyanobprokaryotes exhibited obvious seasonal and local variations at both sampling stations. The highest fresh weight biomass production was recorded in summer at both New Mansoura $\left(214.3 \mathrm{~mm}^{3} \mathrm{~m}^{-3}\right)$ and Bilqas station $\left(161.3 \mathrm{~mm}^{3} \mathrm{~m}^{-3}\right)$, and the lowest in winter at New Mansoura $\left(25.2 \mathrm{~mm}^{3} \mathrm{~m}^{-3}\right)$ and in autumn at Bilqas $\left(30.8 \mathrm{~mm}^{3} \mathrm{~m}^{-3}\right)$. Cyanoprokaryotes standing crop was mainly composed of Chroococcales followed by Oscillatoriales and, a little extent by Nostocales (Fig.6).

\section{Total microcystins in raw and potable waters}

Levels of total microcystins in both raw and potable water exhibited distinct variations (Table 5). Concentrations of total microcystins in raw water ranged between undetected in different times at both station (Table 5) and a maximum value of $2.2 \mu \mathrm{g} \mathrm{l}^{-1}$ recorded during mid-summer at Bilqas station. It is obvious that total microcystins levels were relatively high in summer and low in winter (Table 5). Total microcystins levels of potable water samples were significantly $(\mathrm{p} \leq 0.05)$ lower than those of raw water samples.

Table (5): Periodic variations in concentration of total microcystins in raw and potable water.

Total microcystins $\mu \mathrm{g}^{-1}$

\begin{tabular}{llllll}
\hline \multirow{2}{*}{$\begin{array}{l}\text { Seasonal } \\
\text { period }\end{array}$} & \multirow{2}{*}{ Sampling date } & \multicolumn{2}{c}{ Bilqas } & \multicolumn{2}{c}{ New Mansoura } \\
\cline { 3 - 6 } & & Raw & Potable & Raw & Potable \\
\hline early-Summer & 01-Jul-09 & $\mathbf{1 . 5 0}$ & $\mathbf{0 . 9 0}$ & $\mathbf{1 . 9 0}$ & $\mathbf{1 . 2 0}$ \\
mid-Summer & 12-Aug-09 & $\mathbf{2 . 2 0}$ & $\mathbf{0 . 7 0}$ & $\mathbf{2 . 0 0}$ & $\mathbf{0 . 4 5}$ \\
mid-Autumn & 28-Oct-09 & $\mathbf{0 . 2 5}$ & ND & $\mathbf{0 . 1 6}$ & ND \\
early-Winter & 06-Jan-10 & $\mathbf{0 . 1 7}$ & ND & ND & ND \\
late-Winter & 18-Mar-10 & $\mathbf{1 . 1 6}$ & $\mathbf{0 . 3 0}$ & $\mathbf{0 . 1 6}$ & ND \\
early-Spring & 31-Mar-10 & $\mathbf{0 . 8 4}$ & ND & $\mathbf{0 . 5 4}$ & ND \\
late-Spring & 03-Jun-10 & $\mathbf{1 . 7 0}$ & $\mathbf{0 . 1 1}$ & $\mathbf{0 . 2 4}$ & ND \\
\hline
\end{tabular}

$\mathrm{ND}=$ Not detected

It is evident from Table 5 that microcystins levels of potable waters were almost undetectable when levels of raw water were less than $1 \mu \mathrm{g}^{-1}$. The regression analysis with inversely proportional fit modeling (Fig. 7) indicated significant $(\mathrm{P} \leq 0.05)$ very strong negative correlations $(\mathrm{r}=-0.94)$ between the total microcystins concentration and the residual chlorine of potable water, the two parameters maintained the inversely proportional relationship; Residual chlorine $\left(\mathrm{mg} \mathrm{l}^{-1}\right)=2.3-0.82 \times$ total microcystins of potable water $\left(\mu \mathrm{g}^{-1}\right)$.

Microcystins of some Cyanoprokaryotes species isolated from raw water samples.

Concentrations of microcystins of freeze dried biomass of some Cyanoprokaryotes species isolated from the raw water were calculated from their 
HPLC chromatograms in accordance with the MV peaks of standard microcystinYR and-LR (Fig. 8), with values listed in Table (6). Ten fold differences in microcystins content was recorded with the highest level $3.0 \mathrm{mg} \mathrm{g}^{-1}$ (freeze dried biomass) and lowest $0.3 \mathrm{mg} \mathrm{g}^{-1}$ analyzed in biomass Anabaena oryzae and Anabaena khannae, respectively (Table 6). Microcystins of Anabaena oryzae was chiefly composed of $92 \%$ microcystin-YR and to a minor extent by microcystinLR $(8 \%)$.

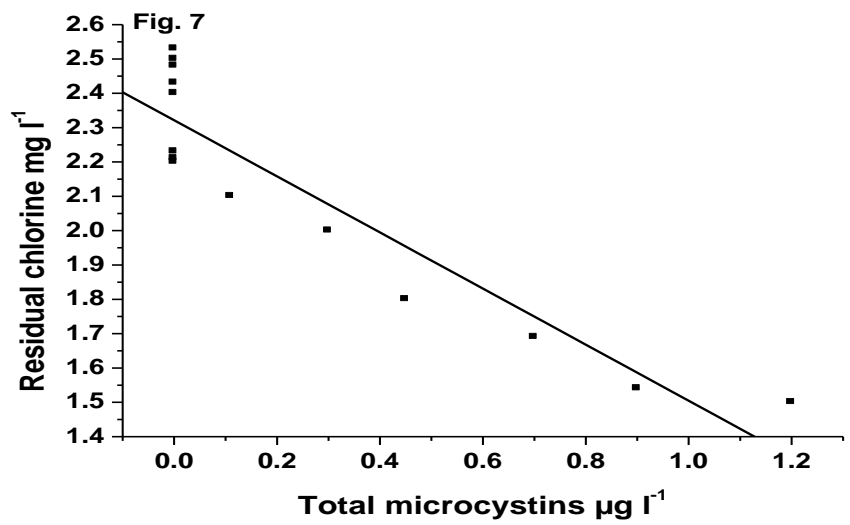

Figure (7): Inversely proportional relationship between total microcystins and residual chlorine of potable water

Marginal contribution of microcystin- YR was detected in biomass of Planktolyngbya limnetica (7.5 \%) and Pseudanabaena limnetica (2.6 \%). Microcystins of the Cyanoprokaryotes namely Anabaena khannae, Planktolyngbya borgerti, Nostoc linckia and Westiellopsis prolifica was composed of $100 \%$ microcystin- LR (Table 6).

Table (6): Concentration of microcystins and \% of microcystin- LR and YR of freeze dried biomass of some cyanoprokaryotes isolates.

\begin{tabular}{|c|c|c|c|}
\hline Cyabobacterial species & Concentration $\mathrm{mg} \mathrm{g}^{-1}$ & \%LR & $\% \mathrm{YR}$ \\
\hline Anabaena khannae Skuja & 0.3 & 100 & $\mathbf{0}$ \\
\hline Anbaena oryzae Fritsch & 3.0 & 8 & 92 \\
\hline Nostoc linckia (Roth) Bornetex Born. et Flash & 0.6 & 100 & $\mathbf{0}$ \\
\hline Planktolyngbya borgerti Lemm & 1.3 & 100 & $\mathbf{0}$ \\
\hline $\begin{array}{l}\text { Planktolyngbya limnetica }(\text { Lemm) } \\
\text { J.K.Legnerová \& G.Cronberg }\end{array}$ & 0.8 & 92.5 & 7.5 \\
\hline Pseudanabaena limnetica (Lemm.) Kom. & 0.9 & 97.4 & 2.6 \\
\hline Westiellopsis prolifica Janet & 0.7 & 100 & $\mathbf{0}$ \\
\hline
\end{tabular}



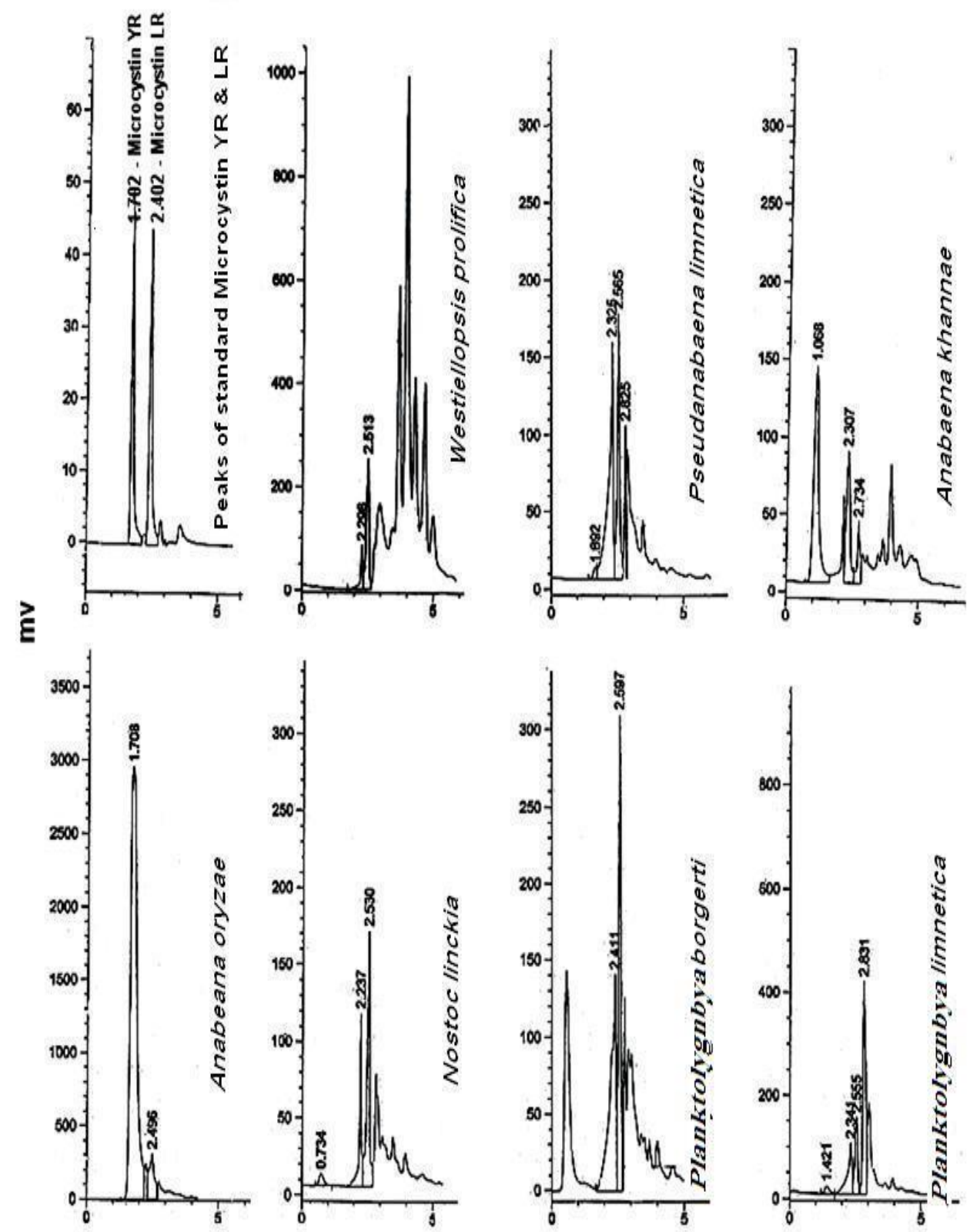

Retention time ( $\mathrm{min})$

Figure (8): HPLC chromatograms of standard microcystin-LR and-YR and methanolic extracts of biomass of some cyanoprokaryotes species 


\section{Relationship between biomass development of Cyanoprokaryotes and some related parameters}

The relationship between biomass development of Cyanoprokaryotes, the corresponding concentrations of photosynthetic pigments, and some controlling physico-chemical parameters was evaluated through multiple correlation analysis (Table 7). The correlated parameters maintained substantially different correlations with both negative and positive coefficients, ranging between strong $(r \geq 0.5)$ and weak $(r<0.5)$ values (Table 7). Striking observation was the absence of any significant correlation between standing crop of Nostocales with any of the correlated parameters.

Table (7): Correlation between some physico-chemical parameters, photosynthetic pigments and cyanobprokaryotes standing crops in raw water collected from New Mansoura and Bilqas. Listed down are the coefficients $(r)$ of the significant $(p \leq .0 .05)$ correlation $(\mathbf{n}=52)$.

\begin{tabular}{|c|c|c|c|c|c|c|c|c|}
\hline & \multicolumn{2}{|c|}{$\begin{array}{l}\text { Chroococcales } \\
\text { biovolume }\end{array}$} & \multicolumn{2}{|c|}{$\begin{array}{l}\text { Nostocales } \\
\text { biovolume }\end{array}$} & \multicolumn{2}{|c|}{$\begin{array}{l}\text { Oscillatoriales } \\
\text { biovolume }\end{array}$} & \multicolumn{2}{|c|}{$\begin{array}{l}\text { Total } \\
\text { Cyanoprokaryotes } \\
\text { biovolume }\end{array}$} \\
\hline & B & NM & B & NM & B & NM & B & NM \\
\hline Temp & 0.36 & 0.47 & - & - & 0.27 & 0.40 & 0.37 & 0.50 \\
\hline pH & -0.37 & -0.40 & - & - & - & - & -0.34 & -0.40 \\
\hline TDS & -0.41 & - & - & - & -0.28 & -0.31 & -0.45 & -0.29 \\
\hline $\mathrm{NH}_{4}-\mathrm{N}$ & - & - & - & - & - & - & - & -0.28 \\
\hline $\mathrm{NO}_{3}-\mathrm{N}$ & - & 0.30 & - & - & - & - & - & 0.28 \\
\hline TP & - & - & - & - & - & - & - & - \\
\hline Chl $a$ & 0.56 & 0.28 & - & - & - & 0.31 & 0.58 & 0.29 \\
\hline Chl $c$ & 0.43 & - & - & - & 0.33 & - & 0.48 & - \\
\hline Car & 0.52 & 0.28 & - & - & - & 0.34 & 0.52 & 0.30 \\
\hline $\begin{array}{l}\text { Chroococcales } \\
\text { biovolume }\end{array}$ & & & - & - & - & 0.34 & 0.96 & 0.95 \\
\hline $\begin{array}{l}\text { Nostocales } \\
\text { biovolume }\end{array}$ & & & & & - & - & - & 0.07 \\
\hline $\begin{array}{l}\text { Oscillatoriales } \\
\text { biovolume }\end{array}$ & & & & & & & 0.39 & 0.54 \\
\hline
\end{tabular}

(-): No significant correlation

Water temperature maintained only positive significant $(\mathrm{p} \leq 0.05)$ correlations with biomass development of Cyanoprokaryotes with coefficient ranged between weak $(r=0.27)$ and strong $(r=0.5)$ values. Chroococcales 
standing crop maintained significant $(\mathrm{p} \leq 0.05)$ weak $(\mathrm{r}=0.3)$ positive correlations with $\mathrm{NO}_{3}$-N. Strong positive significant correlations were recorded between chlorophyll $a$ concentration with the biomass of Chroococcales $(\mathrm{r}=0.56)$ and the total cyanoprokayotes biovolume $(\mathrm{r}=0.58)$. In general, both chlorophyll $a$ and carotenoids exhibited positive significant correlation with cyanoprokaryotes standing crop with coefficient ranged between weak $(r=0.28)$ and strong $(r=0.58)$ values (Table 7).

The total cyanoprokaryotes biovolume maintained very strong positive correlation with Chroococcales at both Bilqas $(r=0.96)$ and New Mansoura $(r=$ 0.95) sampling stations. The correlation analysis indicated also that the biovolume of order Oscillatoriales maintained considerable contribution to the mean annual standing crop of Cyanoprokaryotes at both Bilqas $(r=0.39)$ and New Mansoura $(r$ $=0.54$ ) sampling stations.

The concentration of total microcystins in raw waters was correlated with some physico-chemical parameters and with the cyanoprokaryotes standing crop of the sampled water (Table 8). Total microcystins of raw water maintained significant $(\mathrm{p} \leq 0.05)$ and strong $(\mathrm{r}>0.5)$ positive correlations with water temperature, NO3-N, Chl $a$, Chl $c$, carotenoids and standing crop of Cyanoprokaryotes community (Table 8).

Table 8: Correlation between total microcystins in raw water, some physical and chemical parameters, photosynthetic pigments, and standing crop of cyanoprokaryotes community, Listed are the coefficients ( $r)$ of the significant $(p \leq$ 0.05) correlation $(n=7)$.

\begin{tabular}{lcc} 
& \multicolumn{2}{c}{ Total microcystins } \\
\cline { 2 - 3 } & $\mathrm{B}$ & $\mathrm{NM}$ \\
\hline $\mathrm{Temp}$ & 0.84 & 0.75 \\
$\mathrm{pH}$ & - & - \\
$\mathrm{TDS}$ & - & - \\
$\mathrm{NH}_{4}-\mathrm{N}$ & - & - \\
$\mathrm{NO}_{3}-\mathrm{N}$ & 0.54 & 0.97 \\
$\mathrm{TP}$ & - & - \\
$\mathrm{Chl} a$ & 0.95 & 0.85 \\
$\mathrm{Chl} c$ & 0.71 & 0.83 \\
$\mathrm{Car}$ & 0.92 & 0.70 \\
Chroococcales biovolume & 0.59 & 0.73 \\
Nostocales biovolume & - & - \\
Oscillatoriales biovolume & 0.51 & 0.66 \\
Total cyanoprokaryotes biovolume & 0.58 & 0.78 \\
\hline
\end{tabular}




\section{Discussion}

The present investigation represents an integral part of a comprehensive study that focused on quality characterization of the surface water of the River Nile in Egypt at places supplying raw water for treatment plants providing potable water to about three million capita at Dakahlia Governorate in Egypt. The big size of the served population may highlight the public health relevance of the present study.

Quantitative analysis of hepatotoxin microcystins in raw and drinking water with special emphasis on its seasonal variability, represent the major aim of the present investigation. However, regular periodic analyses of water quality relevant parameters, photosynthetic pigments of phytoplankton in addition to species composition and abundance of Cyanobprokaryotes community were additional research activities maintaining great relevance to the major aim of the study. In this context, it has been thoroughly reported that water temperature, $\mathrm{pH}$ and the concentration of inorganic nitrogen and phosphorus are determinant factors governing field growth and biomass development of planktonic algae including Cyanoprokaryotes (Harris, 1986; Munawar and Talling, 1986; Reynolds, 1982, 1989; Sandgren, 1988).

The results obtained displayed marked seasonal variations in essential plant nutrients ( $\mathrm{N}$ and $\mathrm{P}$ ) and indicated that the biomass development of Cyanoprokaryotes was significantly $(\mathrm{p} \leq 0.05)$ positively correlated with water temperature and $\mathrm{NO}_{3}-\mathrm{N}$ (Table 7). Seasonal variation in chlorophyll $a$ and carotenoids also maintained significant $(\mathrm{p} \leq 0.05)$ and strong correlations $(\mathrm{r}>0.5)$ with the seasonal variations in Cyanoprokaryotes biomass (Table 7) and total microcystins (Table 8). These results were quite expected and were also previously reported for the same study area (Abdel-Aal, 2006; Abdel-Hamid, 1986, 1991; Abdel-Hamid et al., 1992)

This study paid considerable attention to investigate the periodic changes in species composition and abundance of cyanoprokaryotes community since members are the sole source of natural cyanotoxins in freshwater. Cyanoprokaryotes community exhibited substantial seasonal variation in species composition (Table 3) and (Fig. 5) and biomass development (Fig. 6) with the highest species number and standing crop biovolume recorded during summer season. Similar results were identically reported for Nile phytoplankton (AbdelHamid, 1991) and also agreed with those obtained by Robarts and Zohary (1986) who indicated that freshwater Cyanoprokaryotes maintained maximum growth rate and biomass development at water temperature above $25^{\circ} \mathrm{C}$.

Giving detailed data on the seasonal variations of species composition and abundance of Cyanoprokaryotes community (Table 4) is intended to provide base floristic information that may be valuable for other interested researchers. Correlation analysis indicated that members of Chroococcales contributed heavily 
to the standing crop of cyanoprokaryotes community followed by members of Oscillatoriales while Nostocales contribution was lower ranked (Table 7). This was also applicable for microcystins levels in raw water that maintained high significant $(\mathrm{p} \leq 0.05)$ and strong positively correlation $(\mathrm{r}>0.5)$ with the standing crop of Chroococcales, Oscillatoriales and the total cyanoprokaryotes biovolume (Table 8). Accordingly, in this study, the toxigenic Cyanoprokaryotes species were mainly the members of Chroococcales and Oscillatoriales.

Microcystins levels in raw and potable waters were estimated using ELISA technique which is reported as the most promising method for rapid screening of microcystins due to its sensitivity, specificity, and the ease of operation (Sivonen and Jones, 1999). ELISA has been proven to be very sensitive technique for detecting trace amounts of microcystins in water at nannogram levels (Carmichael and An, 1999; Chu et al., 1990). In this study, ELISA technique detected a wide range of microcystins concentration ranging between 0 and $2.2 \mu \mathrm{g}^{-1}$ (Table 5). The highest total microcystins levels of raw water were exclusively recorded in summer coincided with the summer maxima of species richness (Table 3) and biomass standing crop (Fig. 6) of Cyanoprokaryotes. This finding seems very logical and explains the significant ( $\mathrm{p}$ $\leq 0.05$ ) and strong positive correlations between cyanotoxins and abundance of cyanoprokaryotes community (Table 8 ).

Generally the results in Table 5 agreed with those obtained by Kotak $\boldsymbol{e t}$ al. (1996) who found significant increase in microcystins of raw water in midsummer coincided with considerable biomass development of Cyanoprokaryotes. Moreover, Mohammed and Carmichael (2000) reported late summer maxima of

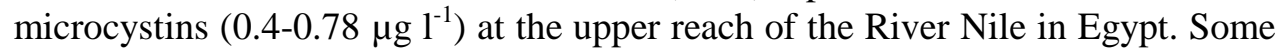
studies (Brittain et al., 2000; Mohamed and Carmichael, 2000; Mohamed, 2001; Mohamed et al., 2006) have already reported the occurrence of toxic Cyanoprokaryotes in Egyptian freshwater resources; however, no evidences have been reported widespread human or animal poisoning of cyanotoxins.

It is perhaps relevant to mention that, during the warmer summer season dense growth of benthic Cyanoprokaryotes was evident on cement walls of the sedimentation basins at both drinking water treatment stations. Microscopic examination of randomly collected samples of benthic Cyanoprokaryotes revealed the predominance of the filamentous species belonging to the genera Oscillatoria, Lyngbya, Pseudanabaena, Anabaena and Calothrix. These benthic Cyanoprokaryotes may include microcystins producing species that can constitute potential additional source of microcystins in potable water especially with aging and decaying of their cells. In this context Berg et al., (1987), Lam et al., (1995), and Lam and Pre-pas (1997) reported that microcystins are endotoxins confined within the cells and released into the surrounding water environment as a result of chemical treatment or natural senescence. Concisely, the abundant summer 
growth of benthic Cyanoprokaryotes on walls of sedimentation basins may also account for the elevated total microcystins levels at potable water during summer season (Table 5). This assumption requires further researches for verification.

Except the microcystins concentration of $1.2 \mu \mathrm{g} \mathrm{l}^{-1}$ which was recorded in early-summer at New Mansoura, microcystins levels in potable water were typically below the WHO guideline level of $1.0 \mu \mathrm{g} \mathrm{l}^{-1}$ (WHO, 1998).

It has been evidenced that chlorine disinfection causes substantial reduction in microcystins levels of potable water (Hitzfeld et al., 2000; Nicholson et al., 1994; Newcombe and Nicholson, 2004).

The present results (Fig. 7) agreed well with these evidences and indicated strong effect of chlorine in reducing total microcystins of potable water inferred by the significant and strong negative correlation between total microcystins and the residual chlorine of potable water. Although there is scarce information about the effects of chlorination of diverse microcystins, Ho et al., (2006) have shown that four common microcystins variants exhibit different reactivity with chlorine following the order microcystin-YR $>-R R>-L R>-L A$. These results indicated that microcystins react with chlorine according to the reactivity of their 2 variable amino acids, and that some rarely occurring microcystins may be resistant to chlorination However, it is admitted that microcystins concentration is efficiently reduced if $\mathrm{pH}$ is maintained below 8 and if $0.5 \mathrm{mgl}^{-1}$ of free chlorine residual is present after $30 \mathrm{~min}$ of exposure.

In an attempt to obtain information about microcystins level in biomass of Cyanoprokaryotes of the studied stations, some species were isolated and cultivated as pure unialgal culture for microcystins analysis. The chief purpose was to establish a sensitive and accurate technique for quantitative analysis of microcystins depending on the available lab facilities. In this regard HPLC analysis (Fig. 8) proved very efficient in quantitative analysis of microcystin-LR and YR of freeze dried cyanoprokaryotes biomass (Table 6). HPLC has been extensively used for the detection of microcystins (Harada, 1996; Lawton et al., 1994).

Besides successful and accurate quantification of their biomass content of microcystins using HPLC technique; the Cyanoprokaryotes isolates listed in Table 6 are, most probably, new records of toxigenic Cyanoprokaryotes of River Nile in Egypt.

\section{References}

Abdel-Aal, E.I. (2006). The use of benthic algae as water quality indicators. M.Sc. thesis, Botany department, Faculty of Science, Mansoura University, Egypt.298p.

Abdel-Hamid, M. I. (1986). Ecological studies on the algal populations of Damietta branch and the possibility of their use as water pollution 
indicators. M. Sc. thesis, Botany department,Faculty of Science, Mansoura University, Egypt.290p.

Abdel-Hamid, M. I. (1991). Phytoplankton and water quality of the River Nile. $\mathrm{Ph}$. D. Thesis, Faculty of Science, Mansoura University, Egypt.346p.

Abdel-Hamid, M. I.; Shaaban-Dessouki, S. A. and Skulberg, O. M. (1992). Water quality of the River Nile in Egypt I. physical and chemical characteristics. Arch. Hydrobiol. Suppl., 90: 283 - 310.

Anagnostidis, K. and Komárek, J. (1985). Modern approach to the classification system of cyanophytes. 1 Introduction. Arch. Hydrobiol. Suppl. 71, Algological Studies, 38/39: 291-302.

Anagnostidis, K. and Komárek, J. (1988). Modern approach to the classification system of cyanophytes. 3. Oscillatoriales. Arch. Hydrobiol. Suppl. 71, Algological Studies, 50-53: 327-472.

Anagnostidis, K. and Komárek, J. (1990). Modern approach to the classification system of cyanophytes. 5. Stigonematales. Arch. Hydrobiol. Suppl. 71, Algological Studies, 59: 1-73.

APHA, (2005). Standard methods for the examination of water and wastewater. 21th Edition. American Public Health Association, American Water Works Association, Water Pollution Control Federation, Washington, DC.10900p.

Berg K.; Skulberg O.M. and Skulberg R. (1987). Effects of decaying toxic blue-green algae on water quality. A laboratory study. Arch Hydrobiol., 108: 549-563.

Brittain, S.; Mohamed, Z. A.; Wang, J.; Lehmann, V. K. B.; Carmicahel, W. W. and Rinehart, K. L. (2000). Isolation and characterization of microcystisn from a River Nile strain of Oscillatoria tenuis Agardh ex. Gomont. Toxicon., 38: 1759-1771.

Carmichael, W.W. (1988). Toxins of freshwater algae. In : Tu A.T. (Ed.): Handbook of natural toxins : Marine toxins and venoms Vol. 3 Marcel Dekker, New York. pp 121-147.

Carmichael, W. W. and An, J. (1999). Using of enzyme linked immunosobent assay (ELISA) and a protein phosphatase inhibition assay (PPIA) for the detection of Microcystin and Nodularin. J. Nat. Toxins, 7: 377-385.

Carmichael, W.W. (2001). Health effects of toxin-producing cyanobacteria: the CyanoHABs. Hum. Ecol. Risk Assess., 7 (5): 1393-1407.

Chu, E. S.; Huang, X. and Wei, R.O. (1990). Enzyme-linked immunosorbent assay for microcystins in blue-green algal blooms. Anal. Chem., 73: 451456. 
Cook, C. M.; Vardaka, E. and Lanaras, T. (2004). Toxic cyanobacteria in Greek freshwaters, 1987-2000: occurrence, toxicity, and impacts in the Mediterranean region. Acta Hydrochim. Hydrobiol., 32 (2): 107-124.

Desikachary, T.V. (1959). Cyanophyta. Indian Council of Agricultural Research, New Delhi, India.686p.

Falconer, I. R. (2005). Is there a human health hazard from microcystins in the drinking water supply? Acta Hydrochim. Hydrobiol., 33 (1): 64-71.

Harada, K. I. (1996). Chemistry and detection of microcystins. In: Watanabe, M.F. Harada, K.I. Carmichael, W.W., Fujiki, H. [Eds] Toxic Microcystis, Chemical Rubber Company (CRC) Press, Boca Raton, Florida, pp103-148.

Harris, G. P. and Trimbee, A. (1986). Phytoplankton population dynamics of a small reservoir: Physical / biological coupling and the time scales for community change. J. Plankton Research, 8: 1011-1025.

Hitzfeld, B. C.; Hoeger, S. J. and Dietrich, D. R. (2000). Cyanobacterial toxins: removal during drinking water treatment, and human risk assessment. Environmental Health Perspectives, 108 (1): 113-122.

Ho, L.; Onstad, G.; Gunten, U.V.; Rinck-Pfeiffer, S.; Craig, K. and Newcombe, G. (2006). Differences in the chlorine reactivity of four microcystin analogues. Wat. Res., 40 (6): 1200-1209.

Jeffery, S. W. and Humphrey, G. F. (1975). New spectrophoto-metric equations for determining chlorophylls $\mathrm{a}, \mathrm{b}$, and $\mathrm{c}$ in higher plants, algae, and natural phytoplankton. Biochem. Physiol. Pflanzen., 167: 191.

Kotak, B. G.; Zurawell, R. W.; Prepas, E. E. and Holmes C. F. B. (1996). Microcystin-LR concentration in aquatic food web compartments from lakes of varying trophic status. Can. J. Fish. Aquat. Sci., 53: 1974-1985.

Komárek, J. and Anagnostidis, K. (1986). Modern approach to the classification system of cyanophytes. 2. Choococcales. Arch. Hydrobiol. Suppl. 71, Algological Studies, 43: 157 - 226.

Komárek, J. and Anagnostidis, K. (1989). Modern approach to the classification system of cyanophytes. 2. Nostocales. Arch. Hydrobiol. Suppl. 71, Algological Studies, 56: 247 - 345.

Lam, A. K. Y.; Prepas, E. E.; Spink, D. and Hrudey, S.E. (1995). Chemical control of hepatotoxic phytoplankton blooms: Implications for human health. Wat. Res., 29: 1845-1854.

Lam, A. K. Y. and Prepas, E. E. (1997). In situ evaluation of options for chemical treatment of hepatotoxic cyanobacterial blooms. Can. J. Fish. Aquat. Sci., 54: 1736-1742. 
Lawton, L. A.; Edwards, C. and Codd, G. A. (1994). Extraction and highperformance liquid chromatographic method for the determination of microcystins in raw and treated waters. Analyst, 119: 1525-1530.

MacKintosh, C.; Beattie, K. A.; Klumpp, S.; Cohen, P. and Codd, G. A. (1990). Cyanobacterial microcystin-LR is a potent and specific inhibitor of protein phosphotases 1 and $2 \mathrm{~A}$ from both mammals and higher plants. FEBS Lett., 264: 187-192.

Matsushima, R.; Yoshizama, S.; Wantanabe, M. F.; Harada, K. I.; Furuzawa, M.; Carmichhael, W. W. and Fujiki, H. (1990). In vitro and in vivo effects of protein phosphatase inhibitors, microcystins and nodularin, on mouse skin and fibroblasts. Biochem. Biophys. Res Commun., 171: 867-874.

Metzner, H.; Rau, H. and Sénger, H. (1965). Untersuchungen zur synchronisierbarkiet einzelner pigmangel-mutantenvon Chlorella. Planta, 65: 186.

Mohamed, Z. A. and Carmichael, W. W. (2000). Seasonal variation in microcystin levels of River Nile water at Sohag city, Egypt Ann. Limnol. 36: 227-234.

Mohamed, Z. A. (2001). Accumulation of cyanobacterial toxins by Daphnia in some Egyptian irrigation canals. Ecotoxicol. Environ. Saf., 50: 4-8.

Mohamed, Z. A.; El-Sharouny, M. H.; Ali, W. S. M. (2006). Microcystin production in benthic mats of cyanobacteria in the Nile River and irrigation canals, Egypt. Toxicon., 47: 584-590.

MWRI (Ministry of water resource and irrigation), 2005. National water resource plan for Egypt. MWRI, Cairo, Egypt.

Munawar, M. and Talling, J. F. (1986). Seasonality of freshwater phytoplankton: A global perspective.- Dr. W. Junk Publishers, Boston. $236 \mathrm{p}$.

Newcombe, G. and Nicholson, B. (2004). Water treatment options for disolved cyanotoxins. J. Water Supply: Research and Technology- AQUA, 63 (4): 227-239.

Nicholson, B. C.; Rositano, J. and Burch, M. D. (1994). Destruction of cyanobacterial peptide hepatotoxins by chlorine and chloramine. Wat. Res., 28 (6): 1297-1303.

Prescott, G.W. (1982). Algae of the Western Great Lakes Area. Second Edition. Otto Koeltz Science Publishers, Koenigstein.293p.

Reynolds, C. S. (1982). Phytoplankton periodicity: its motivation, mechanisms and manipulation.- Report of the Freshwater Biological Association, 50: 60-75. 
Reynolds, C. S. (1989). Relationships among the biological properties, distribution, and regulation of production by planktonic Cyanobacteria. Toxicity Assessment, 4: 229-255.

Robarts, R. D. and Zohary, T. (1987). Temperature effects on photosynthetic capacity, respiration, and growth rates of bloom-forming cyanobacteria. N.Z. J. Mar. Freshwat. Res., 21: 391-399.

Rott, E. (1981). Primary productivity and activity coefficient of phytoplankton of a mesotrophic soft-water lake (Piburger See, Triol, Austria). International Revue de Gesamten Hydrobiologie, 66: 1 - 27.

Sandgren, C. D. (1988). Growth and reproductive strategies of freshwater phytoplankton. Cambridge University Press, Cambridge, pp 9-104.

Sivonen, K. and Jones, G. (1999). Cyanobacterial toxins. In: Chorus, I., Bartram, J. (Eds.), Toxic Cyanobacteria in Water: A Guide to Their Public Health Consequences, Monitoring and Management. E \&FN Spon, London, pp. 41-111.

Skulberg, O. M. (1980). Blue-green algae in Lake Mjøsa and other Norwegian lakes, Progr. Water Technol., 12: 121-140.

Skulberg, O. M.; Codd, G. A. and Carmichael, W. W. (1984). Toxic bluegreen algal blooms in Europe : a growing problem. Ambio., 13: 244-247.

Skulberg, O. M. (1989). Toksinproduserende blagronnalger i norske vanforekomster. Rapporter og Publikasjoner. NIVA: $6 \mathbf{p p .}$

Spoof, L. (2004). High-performance Liquid Chromatography of Microcystins and Nodularins, Cyanobacterial Peptide Toxins. Ph.D. thesis Abo Akademi, University, Turku, Finland pp. 1-72.

Stanier, R. Y.; Kunisawa, R.; Mandel, M. and Cohen-Bazire, G. (1971). Purification and properties of unicellular blue-green algae (order Chroociccales). Bacteriol. Rev., 35: 171-205.

Utermöhl, H. (1958). Zur vervolkommnung der quantitativen phytoPlankton methodik. Mitt. Int. Verein. Limnol. 9: 1 - 39.

WHO, (1998). Cyanobacterial toxins: microcystin-LR. In: Guidelines for drinking water quality. 2nd Edition, Addendum to Vol. 2. Health criteria and other supporting information. World Health Organization, Geneva, Switzerland, pp. 95-110. 


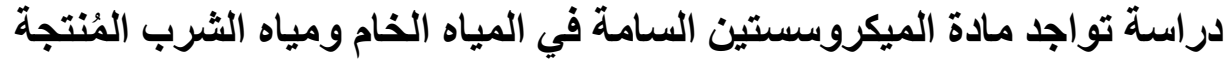 وبعض أنواع السيانوبكتريا (الطحالب الخضراء المزرقة التمة) المعزولة من مصادر

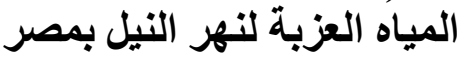

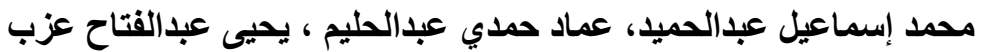

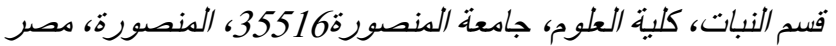

استهدفت الدراسة التحديد النوعي والكمي لمادة الميكروسستين السامة في مياه نهر النيل الخام

ومياه الشرب المُنتجة وبعض عزلات الطُ الطحالب الخضراء المزرقة التي تنمو في مياه نهر النيل. ولهذاه

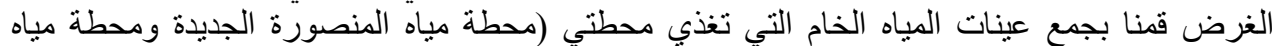

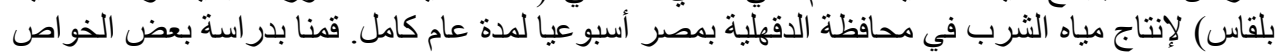

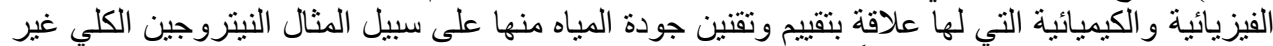

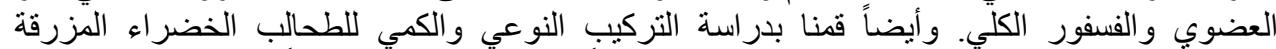

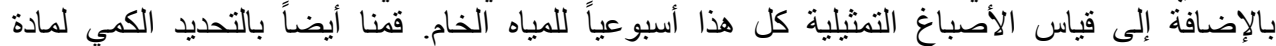

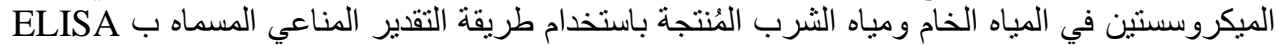

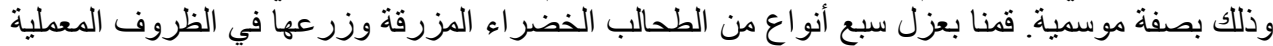

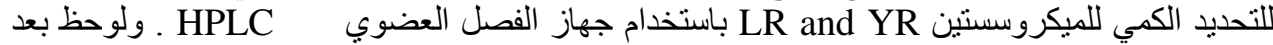

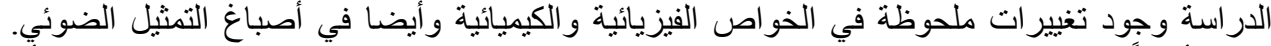

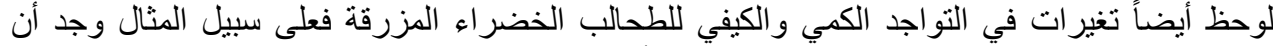

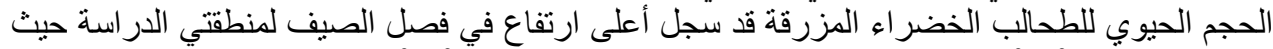

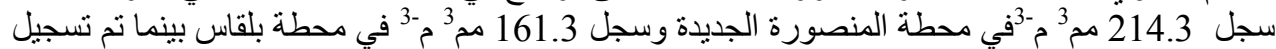

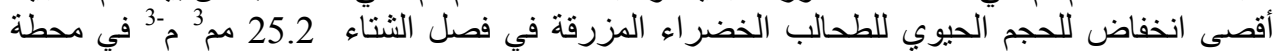

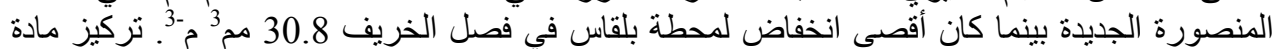

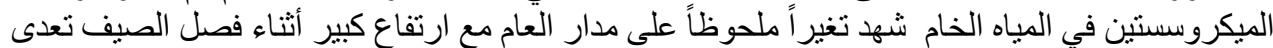

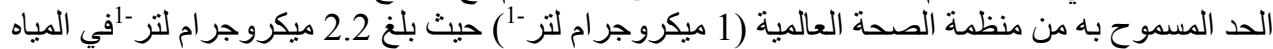

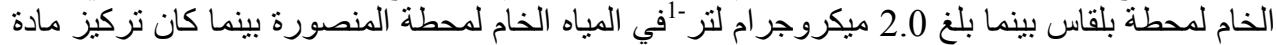

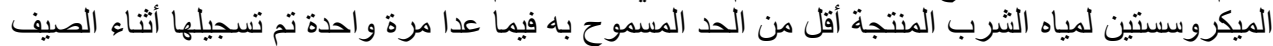

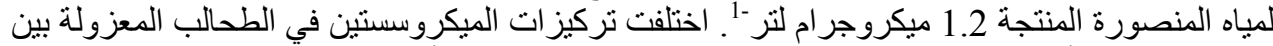

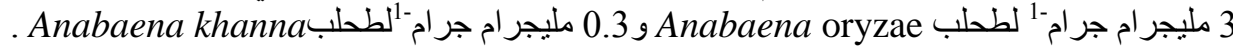

